\title{
O Mercado Interno na América Portuguesa: "Exclusivo" Metropolitano do Comércio Colonial e os "Descaminhos do Sal" na Capitania de São Paulo na Primeira Metade do Século XVIII *
}

\author{
Artur José Renda Vitorino \\ Professor - Faculdade de História - Programa de Pós-Graduação em Educação da PUC- Campinas \\ Endereço para contato: Complexo CCHSA - Rodovia Dom Pedro I, KM 36 \\ Parque das Universidades - Campinas - SP - CEP: 13086-900 \\ E-mail: arturvitorino@puc-campinas.edu.br
}

\section{Diego Danilo Rizzi}

Bacharel e Licenciado em História - PUC- Campinas

Endereço para contato: Rua Paraíba, 66, Jardim Magali - Itapira-SP - CEP: 13972-060

E-mail: rizzi.dd@gmail.com

Recebido em 03 de março de 2011. Aceito em 24 de outubro de 2011.

\section{Resumo}

Este artigo visa analisar as atividades mercantis de Francisco Pinheiro, mercador português de grosso trato, e seus agentes comerciais na capitania de São Paulo na primeira metade do século XVIII, com o comércio do sal, produto monopolizado pela Coroa portuguesa. Contudo, o contrato do sal ofereceu à sua agência muito mais embaraços do que um meio seguro de amealhar riquezas, pois se deparou com a concorrência ilegal dos "donos do sal" presentes na região e a interferência das Câmaras Municipais em seus negócios.

\section{Palavras-Chave}

história regional, exclusivo comercial, sal, São Paulo colonial

\begin{abstract}
This article aims to analyze the trading activities of Francisco Pinheiro, portuguese merchant of wholesale trade, and his commercial agents in the Captaincy of São Paulo in the first half of the XVIII ${ }^{\text {th }}$ century, with the salt trade, monopolized product by the portuguese Crown. However, the salt contract offered to your agency more embarrassment than a secure way to amass wealth, as he faced competition from illegal "owners of the salt" in the region and the interference of municipalities in his business.
\end{abstract}

\section{Keywords}

regional history, commercial exclusive, salt, colonial São Paulo

\section{JEL Classification}

N5, N9

- Os autores agradecem os pareceristas anônimos desta revista pelas contribuições, no sentido de azeitarem os argumentos aqui expostos. Ainda, os autores agradecem o CNPq pela bolsa concedida de IC. Este artigo é um desdobramento de Iniciação Científica desenvolvida na PUC-Campinas sob orientação do Prof. Artur J. R. Vitorino. 


\section{Introdução}

Com as descobertas auríferas em Minas Gerais e, posteriormente, em Mato Grosso e em Goiás, no decorrer da primeira metade do século XVIII, boa parte da população das regiões litorâneas, bem como da metrópole portuguesa, enveredou-se para o interior, promovendo um alargamento no processo de povoação, colonização e ampliação de mercados e negócios. Por um lado, a abertura dessas novas rotas comerciais significou para a Coroa portuguesa o reforço de sua presença política na colônia e a possibilidade de garantir novas fontes de recursos, isto tanto através da intensificação tributária sobre a extração do ouro, quanto da criação de barreiras comerciais, de arremate de cargos e da concessão de monopólios e cargos públicos. Por outro lado, comerciantes e negociantes viam nessas regiões novos mercados para acumular riquezas, fornecendo uma gama de produtos para aquela população, como fazendas secas e molhadas, escravos, artigos de luxo, gêneros de primeira necessidade.

Consolidar-se no mercado mineiro exigia, contudo, a associação de comerciantes com o próprio Estado português, que, por sua vez, contava com tal apoio para concretizar seu projeto colonizador. " $\mathrm{Na}$ medida em que os grandes comerciantes eram os únicos que acumulavam capitais vultuosos e tinham interesse em investir em negócios, eram eles os parceiros ideais no empreendimento colonial. Por isso, foram constantemente invocados a financiar o Reino em apuros, ou a arrematar os diferentes contratos para a exploração de produtos coloniais." (Furtado, 1999, p. 35) Dentre os comerciantes do Reino, encontramos os mercadores de grosso trato, homens de negócio que se definiam através da pluralidade de seus empreendimentos, investiam seus cabedais em uma gama de negócios, variando suas atividades e seus interesses no vasto Império marítimo, seja com a exportação e importação de bens de consumo, seja com fazendas secas e molhadas, empréstimos, arrematação de contratos e de monopólios, arrendamento de cargos.

Jorge Pedreira (1996) aponta que os negociantes de grosso trato, constituindo-se como elite mercantil, mantinham seus capitais em giro permanente no comércio ultramarino, pois sustentavam a maior parte do comércio internacional e, assim, desfrutavam vantagens, inserindo-se em redes mercantis locais, o que facilitaria a obtenção de mercadorias para exportação e o fornecimento dos produtos 
do reino, mediado pela ação de agentes comerciais nestas praças. Ao investir seus cabedais nas mais diversas formas de atividade mercantil, firmavam-se em uma avaliação, ainda que imprecisa, dos riscos e das possibilidades de lucro, oscilando em suas práticas mercantis e otimização financeira, preferindo, por vezes, a lucratividade do investimento; outras, a sua segurança (Pedreira, 1996, p. 377).

Um destes mercadores de grosso trato que se aventurou no mercado interno da América portuguesa dos Setecentos, observando próspera oportunidade de ampliação de lucros e de sua empresa mercantil, fora o mercador português Francisco Pinheiro. Nascido em Alcochete, Portugal, por volta do início do último quartel do século XVII, filho de padeiros e neto de barqueiros, começou a trabalhar nas salinas de Setúbal. Em 1695 encontrava-se estabelecido em Lisboa como comerciante de sal, cujo contrato de fornecimento para a cidade teve em mãos de 1717 a 1731, bem como outros ramos comerciais: tecidos, gêneros alimentícios, manufaturas, barras de ferro, negros e até práticas de empréstimo de dinheiro. Consolidou-se na praça lusitana como comerciante de grosso trato, fixando agências nas diversas regiões comerciais espalhadas pelo vasto Império marítimo português: na América portuguesa, Ásia, África e Europa. Faleceu em 1749, e, não possuindo herdeiros diretos, a maior parte de suas fortunas e documentação passaram para o Hospital Real de todos os Santos (Cf. Ellis, 1982, p. 120). A comunicação entre Pinheiro e seus agentes dava-se através de cartas comerciais. "Essas cartas cumpriam duas funções - vigiar e orientar os seus comissários e informar-se das melhores oportunidades comerciais." (Honda, 2004, p. 9)

De acordo com a documentação ativa e passiva, Francisco Pinheiro estabeleceu sua primeira agência na América portuguesa na região de Pernambuco por volta de 1704, estendendo-se para o Ceará, Bahia, Rio de Janeiro, Minas Gerais, Colônia do Sacramento, Goiás e Mato Grosso. Em São Paulo, fixou sua agência em 1727, na vila de Santos, após ter arrematado em Lisboa o contrato do sal para abastecer a capitania paulista no triênio 1728-1730. Longe do que a tradicional his-

\footnotetext{
1 As cartas comerciais de Francisco Pinheiro e seus agentes foram transcritas e organizadas na coleção Negócios Coloniais, em cinco volumes, graças ao árduo e profícuo trabalho de Luís Lisanti Filho (1973), com o financiamento do Ministério da Fazenda. Esta documentação permite-nos o conhecimento da movimentação financeira do comerciante português no Ultramar e os principais aspectos do mecanismo comercial entre Portugal e Brasil (Cf. Ellis, 1982, p. 120), além das demais regiões do Império português.
} 
toriografia paulista defendera acerca de sua "decadência" e "pobreza" em relação a outras regiões coloniais e da própria dinâmica mercantil atlântica, ou de seu papel autônomo, intransigente e rebelde face ao poder de Portugal, forjando o típico conquistador dos sertões. ${ }^{2}$

São Paulo constituiu um importante mercado no cenário colonial. Ilana Blaj (2002), Milena Maranho (2006) e Maria Aparecida de Menezes Borrego (2006) enfatizam o alto grau de mercantilização de São Paulo colonial e a cristalização de elites locais, basicamente estruturadas para atender à demanda interna da América portuguesa. Ilana Blaj (2002), em seu primoroso trabalho A trama das tensões, observa que no final do século XVII e início do século XVIII, houvera um processo de mercantilização crescente em São Paulo, inserindo-a e articulando-a nos quadros do Antigo Sistema Colonial: a vila seria agente de colonização, conquistando núcleos mais distantes, integrando-se ao Império português e, mediante atividades produtivas e mercantis, garantiria o abastecimento das áreas exportadoras e interioranas, além de prover o sustento dos funcionários da Coroa residentes no local (Blaj, 2002, pp. 202-203). Antes mesmo do comércio com as áreas mineratórias, este processo se estendia; a descoberta das minas apenas acentuou a dinâmica comercial de abastecimento interno, sedimentando gradativamente o processo de mercantilização em São Paulo e consolidando sua elite. "Comercializando toda uma produção local e de outras regiões, articulando bairros rurais e vilas interioranas, suprindo os centros mineradores e as demais capitanias, São Paulo colonial configura-se como uma área de abastecimento interno nos quadros da colônia." (Idem, p. 343) Assim, Blaj constata que a especificidade de São Paulo deriva de sua própria dinâmica interna, por ser referência no abastecimento interno e articulando-se com as demais regiões e capitanias, especialmente as exportadoras.

Milena Maranho (2006), ao promover uma história comparada entre São Paulo e Pernambuco, problematiza a "pobreza" e a "riqueza", respectivamente, destas capitanias, levando em consideração o papel e as especificidades que ambas apresentavam no Império colonial português: São Paulo contribuiu para o abastecimento interno de regiões da América portuguesa, inclusive abastecendo Pernambuco; por sua vez, esta capitania fornecia açúcar para o mercado externo. Até o período aurífero, recaía o interesse régio pela região exporta-

2 Sobre esta discussão historiográfica acerca de São Paulo colonial, ver Blaj, 2002, pp. 39-88 e Borrego, 2006, pp. 12-34. 
dora; com as descobertas do ouro, mudou-se o foco dos interesses e "mudaram as engrenagens políticas do mundo atlântico português, em detrimento das localidades produtoras de açúcar." (Maranho, 2006, p. 239) Contudo, as atividades econômicas de ambas as regiões ocorriam concomitantemente à construção do processo colonizador, e os processos de economia de subsistência às regiões exportadoras e de economia voltada à exploração agrícola ou de minérios não eram excludentes, tampouco antagônicas. Afinal, São Paulo e Pernambuco apresentavam um substrato comum no processo de colonização, qual seja, o sucesso da empresa colonial mediante a aquisição de lucros, seja para a Coroa, seja para os súditos; este processo ora convergia para as partes, ora agravava discordâncias dos interesses do processo colonizador, gerando, assim, a constituição de diferenciações regionais (Cf. Idem, p. 360).

Ao traçar as práticas mercantis e o enriquecimento material, a conquista de bens simbólicos de prestígio de mercadores e homens de negócios presentes em São Paulo e a "teia mercantil", delineada durante a primeira metade do século XVIII, Maria Aparecida de Menezes Borrego (2006) menciona que São Paulo era local privilegiado para expandir tais redes comerciais e sociais, por localizar-se no centro de convergência de caminhos comerciais, interligando as demais vilas paulistas, o porto de Santos e as regiões auríferas de Minas Gerais, Cuiabá e Goiás ao Rio de Janeiro. Seus negócios permeavam dívidas que se estendiam às relações mercantis e pessoais dos dois lados do Atlântico, hierarquizando homens em redes intercambiáveis de controle e de sujeição (Borrego, 2002, p. 313).

O acúmulo de fortuna não representava, nesta sociedade, a coroação de prestígio e honra; o reconhecimento social confirmava-se com a participação nas instâncias de decisão política, como a Câmara Municipal ou a Santa Casa de Misericórdia. Para a autora, o patrimônio líquido destes homens de negócios e mercadores não alcançava as cifras de outras praças comerciais, como a do Rio de Janeiro, por ser uma região vinculada ao comércio no Atlântico (Cf. Idem, p. 233), porém, não identifica nem pujança, tampouco decadência, haja vista que "a avaliação dos patrimônios líquidos do segmento mercantil inventariado indicou uma profunda desigualdade econômica entre os agentes atuantes em solo piratiningano." (Idem, p. 317) 
Constatamos, assim, a predominante atuação da capitania no cenário colonial pelas vias do abastecimento interno, contemplando as demandas de mercados que privilegiavam o comércio atlântico, sejam as regiões auríferas ou as regiões dos engenhos. Mais que isso, este processo de mercantilização possibilitou a cristalização de uma elite responsável por atender a esse mercado interno. Como tal, a sedimentação dessa elite paulista fez emergir interesses locais que, por vezes, aproximava-se dos interesses régios em promover a colonização e em transferir os proventos e os tributos aos cofres da Coroa; por vezes, a ação desta elite, que ocupava órgãos de poder e prestígio na sociedade colonial, tencionava-se com a ação régia, interferindo na dinâmica de acumulação de riquezas e de poder.

Para inserir-se nestas redes mercantis, Francisco Pinheiro arrematou o contrato de fornecimento do sal para a região. Monopólio privilegiado pela Coroa, o sal garantia aos representantes da classe mercantil metropolitana, mediante concessão régia, a exclusividade de produção e a aquisição do produto para vendê-lo tanto na Colônia como na Metrópole, controlando os preços de produção, de mercado e de revendas nas colônias a preços monopolistas (Cf. Ellis, 1982, p. 99). Pois bem, através da concessão régia para produtos considerados exclusivos pela Coroa, o comerciante buscaria um meio fácil de enriquecimento e influência (Pedreira, 1996, p. 361), fugindo de uma larga margem de lucros, pois o preço de venda estava previamente fixado pelo contrato. Todavia, garantia ao arrematante a exclusividade do mercado consumidor. Mas antes de ser mais uma oportunidade comercial para amealhar riquezas, deparou-se com empecilhos do mercado local e prejuízos sofridos graças aos "descaminhos do sal" na capitania paulista, levando, inclusive, o Conselho Ultramarino a revogar o contrato régio para o triênio. A agência não contava com a atuação marginal dos "donos do sal" e a inoportuna interferência das câmaras municipais.

Sendo assim, constituiremos este artigo, além desta Introdução, em mais três seções, incluindo a conclusão. Discutiremos a questão do monopólio e do sal na história colonial, em um primeiro momento, e, posteriormente, entender a configuração da capitania de São Paulo no que tange ao comércio do sal para Santos, São Paulo, os sertões e minas do ouro. 


\section{O Monopólio e o Sal no Período Colonial}

Fernando Novais (2001) conceituou a questão dos exclusivos comerciais pela Coroa como um dos pontos basilares do que denominou de Antigo Sistema Colonial. Ponto nevrálgico da colonização na Era Moderna, o regime comercial ditado pelo "monopólio colonial" - ou "exclusivo metropolitano" - "constituía-se pois no mecanismo por excelência do sistema, através do qual se processava o ajustamento da expansão colonizadora aos processos da economia e da sociedade europeias em transição para o capitalismo integral." (Novais, 2001, p. 72) Firmando a metrópole e a colônia eixos institucionais de transferência de excedentes em benefício da Coroa para o bom funcionamento dos laços de dependência das áreas ultramarinas, Novais cristaliza a ideia de que estas relações estimulam a acumulação primitiva do capital, incrementando as atividades mercantis de ocupação, povoação e valorização dessas áreas coloniais. Por meio do exclusivo, dispunham os burgueses mercantis da oferta dos produtos, garantindo sobrelucros, tanto na compra, pois os custos de produção estavam abaixo dos preços internacionais, como na venda, haja vista o monopólio no mercado colonial. Esta política econômica adotada pela Coroa, o Mercantilismo, favorecia os cofres lusitanos, pois transferiam rendas régias da colônia para a metrópole e aos empresários lusos envolvidos no comércio ultramarino.

Por sua vez, João Fragoso e Manolo Florentino (1993) redefinem o processo de acumulação de capitais no cenário colonial. A acumulação mercantil fundamenta um modelo arcaico de sociedade e a colonização ultramarina que, ao transferir as rendas coloniais para a metrópole, sustenta uma estrutura parasitária, consubstanciando uma hipertrofia do Estado e a hegemonia de um grupo de grandes comerciantes que ingressarão no mundo aristocrático, os fidalgos-mercadores.

A extração dos excedentes coloniais, contudo, não fomentaria uma "transição a um capitalismo integral", como nos diz Fernando Novais: por haver nesta sociedade prevalência de valores não capitalistas, "a atividade mercantil lusitana tem por fim último a permanência temporal de uma sociedade arcaica, pelo que ela não chega a assumir a função revolucionária que desempenha em outros países." (Fragoso e Florentino, 1993, pp. 27-28) A sequela da colonização é sentida quando "[o]ferecia-se, ademais, a possibilidade de gestação e 
desenvolvimento de poderosas comunidades mercantis nos trópicos, possibilidade esta que, de uma forma ou de outra, contribuiu para a consecução do projeto arcaico metropolitano." (Idem, p. 102)

Ambos os argumentos, contudo, apresentam um ponto comum: a transferência de capitais para a metrópole lusitana seja para alavancar o capitalismo, seja para manter uma sociedade arcaica pautada em valores nobiliárquicos. Uma das formas de obter os excedentes era através dos monopólios. Myriam Ellis (1982) explica que essa política mercantilista de concessões régias de exclusivos solucionava as aperturas financeiras da Coroa, pois "o Estado percebia antecipadamente determinados rendimentos destinados a enfrentar as muitas vezes prementes necessidades do Tesouro." (Ellis, 1982, p. 99) Afinal, o Erário Régio era sustentado pelos rendimentos auferidos por esses contratos, gerenciando a negociação desses monopólios a particulares, a classe burguesa. Aos contratadores, arrendatários dos exclusivos e sócios temporários da Coroa, cabia cumprir as cláusulas contratuais e efetuar os pagamentos à Fazenda sobre os direitos de exploração dos estancos, e esta participação na vida econômica repercutia na própria atuação política dentro da Corte portuguesa.

Luiz Antônio Silva Araújo (2002) endossa o argumento da autora ao analisar os contratos régios sobre o direito de tributação sobre passagens, dízimas e entradas nas Minas setecentistas. Com a finalidade de controlar as atividades comerciais nas regiões auríferas e evitar o contrabando do ouro, de diamantes e mercadorias, intensificou-se naquela região colonial o aumento do aparato burocrático-militar lusitano. Mineração, produção de gêneros alimentícios e o comércio eram as principais fontes de ascensão social. "Junto com tais atividades e o incremento da economia colonial e dos negócios lusitanos, cresceu também no Brasil e em Lisboa a atuação dos contratadores, inclusive para aqueles que se voltam para a arrematação de contratos envolvendo tributos." (Araújo, 2002, p. 58) João de Souza Lisboa, mercador português radicado em Minas Gerais e objeto de estudo de Luiz Araújo, é um desses mercadores que fez sua riqueza como contratador na região. Lançando mão do exclusivo fiscal, a Coroa, favorecida pelo arremate, concede ao negociante a prática fiscal em Minas que, ao cercear o mercado local, angaria os pagamentos tributários sobre entradas de mercadorias e sobre a produção de gêneros, alcançando, assim, riqueza e prestígio. "A atuação estatal através de particulares, com os quais a Coroa estabelece relações contratuais, 
foi prática importante nas monarquias ibéricas, caminho de excedente colonial para a metrópole e enriquecimento para homens de negócio tanto em Portugal como no Brasil.” (Idem, p. 64)

Além dos contratos sobre tributos, a Coroa portuguesa detinha os estancos de importantes produtos, tais como os da pesca do coral, do marfim, de escravos, das especiarias, das alfândegas, da prata, do cobre, dos açúcares, do pau-brasil, da pesca da baleia, do tabaco, do sal, dos dízimos, dentre outros. Sobre o monopólio do sal, possuiu grande relevo na vida econômica de Portugal, tido como uma espécie de "ouro branco" (Garcia, 1984, p. 9). Produto de variadas funções, desde as domésticas até a salga, conserva de carnes e na engorda do gado, a indústria salineira ocupou grande destaque na ativação do comércio interno e externo, haja vista a posição geográfica privilegiada para a extração do sal no litoral lusitano. Setúbal e Alcácer do Sal, localizadas na região do baixo Sado português, foram as cidades que mais prosperaram, a partir da Idade Média, com atividades ligadas ao mar, seja a pesca ou a exploração e exportação do sal. "Setúbal, de pequena aldeia no século XIII, a vila muralhada no século XIV, tem um crescimento que constitui um facto dependente daquela realidade econômica, completada, como é lógico, pela exploração de um fértil alfoz agrícola." (Idem, p. 10)

"A importância do sal não lhe advinha da fiscalidade ou dos forais, mas da sua real valia e peso na economia do reino. Mas, sendo um produto feito por mão de homem e de grande utilidade quotidiana, não podia deixar de ser aproveitado como fonte de receitas e de ingressos para o Rei, para os Senhores ou para os municípios. [...]" Como mercadoria comercial foi tão importante que deu origem a um grupo de mercadores como identidade própria, os chamados "saleiros". (Silva, 2005, p. 74)

O sal representou grande peso na história de Portugal, já que era com a sua exportação para áreas coloniais que, em traços largos, conseguia-se uma estabilidade possível da economia portuguesa e a manutenção de um Estado que favorecia a consolidação de estratos sociais dominantes ou mesmo a emergência de novos comerciantes, 
como o caso de Francisco Pinheiro que, conforme citado, iniciou suas atividades mercantis justamente nas salinas de Setúbal, sendo um destes "saleiros" do reino. Os efeitos mais significativos da produção salineira lusitana permitiram aos detentores de capital econômico e social o acesso, através de compra, doação ou usurpação, ao salgado de Setúbal, integrando este novo grupo, formado pela pequena nobreza e por burgueses endinheirados que, rapidamente, cristalizaram-se enquanto setor econômico. Pelo monopólio estatal do comércio do sal e as apertadas regulamentações que de Lisboa condicionavam o mercado salineiro, multiplicaram-se e consolidaram-se as fortunas desses comerciantes do sal, haja visa as excelentes condições de produção e os elevadíssimos índices de produtividade (Cf. Abreu, 2005, pp. 332-333).

Myriam Ellis (1955), agora em O monopólio do sal no Estado do $\mathrm{Brasil}^{3}$ analisa o exclusivo comercial do produto entre o período de 1631 a 1801. O controle sobre o trato salineiro remonta aos primórdios da nação lusitana, pois ao rei pertencia mar, rios, lagoas, e os direitos sobre os seus rendimentos eram passíveis de arrendamento (Cf. Amorim, 2008, p. 184). Durante a União Ibérica (1580-1640), o rei Filipe IV de Espanha e III de Portugal fortalece a política de monopólios, impondo o controle da produção e distribuição sobre as salinas portuguesas, integrando-as ao monopólio do sal castelhano. A medida visava a penetração do sal espanhol nos mercados europeus, pois contava com as salinas portuguesas para alargar seu espaço econômico. Ao estruturar o controle da produção e dar contornos organizativos para filtrar o contrabando e os interesses de centros produtores mercantis portugueses, a centralização sobre a produção salineira culmina com a prática do monopólio do produto (Cf. Idem, pp. 184-185).

As rendas oriundas com o estanco para o Estado do Brasil seriam revertidas para recuperar o Erário Régio e defender o reino de invasores ${ }^{4}$ além de retomar Pernambuco do domínio holandês. Após a Restauração em 1640, Portugal continuou a gerenciar, por quase

3 O Estado do Brasil compreendia as seguintes regiões: Capitania da Bahia e anexas (Sergipe, Ilhéus e Porto Seguro); Capitania de Pernambuco e suas subalternas (Paraíba, Rio Grande do Norte); a Capitania do Espírito Santo; a repartição sul da Capitania do Rio de Janeiro e a Capitania de São Paulo, até 1613. No século XVIII, novas capitanias incorporam esta divisão administrativa da Coroa no Brasil, sendo elas, Minas Gerais, Rio Grande do Sul, Goiás e Mato Grosso. Ellis, 1955, pp. 24-25.

4 De acordo com Amorim (2008), o papel do imposto do sal para as finanças públicas de Portugal estavam ligadas particularmente com o suporte de guerra (Amorim, 2006, p. 184). 
dois séculos, esta interessante fonte de renda para o erário régio sob o argumento de que os proventos oriundos do exclusivo comercial do sal serviriam para a defesa da colônia contra o invasor externo e, assim, manter guarnições militares no litoral. Contribuiu também para reconstruir o país após a Restauração da Casa de Bragança, sanar a decadência da lavoura canavieira (nos finais do século XVII) e o estabelecimento de mercados no interior luso-americano, fazendo emergir, assim, no início do século XVIII, uma grande área consumidora de sal, aumentando conforme o crescimento da população. Para assegurar o monopólio, a Coroa limitou a produção e extração do sal no Estado do Brasil, permitindo às salinas do Maranhão e do Rio Grande do Norte a continuidade da produção salineira, apenas para o abastecimento regional.

O rei recebia adiantadamente os lucros líquidos sobre a venda do sal para gastos imediatos; o contratador, muitas vezes, ficava em desvantagem, devido às dificuldades que porventura surgissem, como o atraso das embarcações e o contrabando do produto nas áreas coloniais. Aos contratadores do sal estavam reservados os direitos de formar o seu próprio pessoal para conduzir os negócios do sal. Obedecendo diretamente às ordens do contrato régio, estes homens eram responsáveis pela dinamização do comércio do sal, abastecendo o mercado interno, resolvendo conflitos com os atravessadores e contrabandistas do sal e impedindo a interferência de comerciantes e de poderes locais no contrato, como as câmaras municipais, caso lançassem tributos sobre a circulação do produto.

Normalmente, a abrangência do contrato do sal contornava todo o Estado do Brasil. Para o triênio 1728-1730 o contrato fora desmembrado em três regiões: Capitania de Pernambuco e anexas; Rio de Janeiro e São Paulo. Contudo, grandes transtornos surgiram. O abastecimento de São Paulo e Minas Gerais era feito pela praça comercial do Rio de Janeiro; Santos o recebia de Pernambuco, Bahia e Rio de Janeiro. Mas o parco abastecimento do sal para a região, algo em torno de 6 a 7 mil alqueires de sal, não conseguia suprir o mercado paulista, acarretando a especulação sobre o produto. A Coroa, assim, optou pela criação de um contrato em separado ao do Rio de Janeiro, como única solução para o abastecimento da capitania (Idem, p. 65). 


\section{Os "Descaminhos do Sal" em São Paulo}

O negócio do sal era muito atraente e lucrativo na América portuguesa, tanto que um de seus agentes, João Diniz de Azevedo, lotado na capitania do Rio de Janeiro, diz que "o negócio do sal he o milhor que ha para estas partes (...) [os comerciantes] farão grandes negócios tambem quem correr com elle nesta cidade pois tem grandes comveniencias em mandar as minas e para outras partes aonde o não o ha $o$ vendem pello que querem." (Lisanti Filho, 1973, vol. 2, p. 108, Carta 257) Na capitania de Pernambuco conseguira bons retornos financeiros com o comércio do sal, sendo a mercadoria que mais relevância assumiu nas importações. Entre 1713 e 1715, período no qual houve maior fluxo de correspondências e, consequentemente, de negócios, importou-se 349 moios de sal (Idem, vol. 1).

$\mathrm{Na}$ torna-viagem, um produto típico e altamente lucrativo no mercado europeu: o açúcar. "Senhor fico entregue das 9 caixas de asucre que Vossa Mercê remeteo por conta do sal que remeti a Vossa Mercê." (Idem, vol. 4, p. 617, Carta 875) Branco ou mascavado, Francisco Pinheiro o comercializava no mercado europeu, pois os campos cultivados de cana-de-açúcar se constituíam em função de centros urbanos europeus e de seus consumidores (Cf. Idem, vol. 1 p. CXIII ). Buscando extrair vantagens comerciais com os negócios do sal, em sociedade com Vasco Lourenço Velloso, fiador do contrato, e João Alvres, contratador do monopólio e seu cunhado, Francisco Pinheiro arrematou o direito do comércio do sal para a região de Santos, São Paulo e todo o sertão e Minas, entre os anos de 1728 e 1730. Pagando propinas aos órgãos da administração portuguesa que atingiram a soma de 413.730 rs (Idem, vol. 5, Carta 1361, p. 374), conseguiu a sociedade no contrato do sal. Para desempenhar as funções no trato do sal, Pinheiro enviou para a capitania três agentes mercantis: Pedro Fernandes de Andrade, designado a ser administrador do sal ${ }^{5}$ na capitania de São Paulo; João da Roza e Francisco Marques, seu afilhado. Também participou o juiz-de-fora Bernardo Ruiz do Valle como conservador do sal, ${ }^{6}$ pois, como "o estanque do

5 "Tinham, em geral, por função, a administração do estanque no Reino e no Brasil, a venda do sal do contrato e a fiscalização do embarque do gênero na Metrópole e o desembarque nos portos de estanque do Brasil. Também possuíam, como os Contratadores, privilégios para a cobrança executiva das dívidas do contrato, jurisdição sobre quaisquer escrivães, mesmo os do estanque, para passarem precatórias e mandados necessários contra os devedores". Ellis, 1955, pp. 103-104.

6 Aos conservadores cabia conhecer, tratar e julgar todas as questões relativas ao contrato e aos funcionários do referido estanque. Escolhidos pelo contratador, tinham privilégios conferi- 
sal do destricto dessa vila de Sam Paullo e seus lemites de ha de ser precizo valer da muita honrra e favor que Vossa Mercê me faz e hei de pedir no dito conselho [ultramarino] provizão para Vossa Mercê ser nosso conservador..." (Lisanti Filho, vol. 5, p. 373, Carta 1361)

As condições do contrato, basicamente, impuseram que o sal em Santos, São Paulo, sertão e as minas fosse monopólio destes comerciantes, com direito à ida de três frotas para o abastecimento do mercado, tendo de se pagar para a fazenda real dezoito mil cruzados ao ano, além dos direitos tributados a cada alqueire vendido. Tendo de abastecer o mercado paulista e das minas e sertões com 662 moios de sal, o preço de venda, autorizado pelo Conselho Ultramarino, seria de 1.920 rs o alqueire, sendo de responsabilidade do arrematante o armazenamento, bem como a descarga, em navios que só conduzam o dito produto (Cf. Idem, vol. 4, pp. 167-170). Conforme carta de 15 de abril de 1727, Francisco Pinheiro envia instruções acerca do contrato do sal, como esta que abaixo segue:

"Como rematamos o contracto do sal da vila de Santos, São Paulo; e seus destrictos, que ha de ter principio em o primeiro de janeiro próximo que vem de 1728 , nos foi precizo de ja cuidar no provimento da dita praça para o que frettamos a charrua N. Sr. ${ }^{a}$ da Nazarethe Santa Anna na qual carregamos de nossa conta 662 moios de sal como consta de conjunto junto; (...) na descarga da d. charrua pedimos a Vossa Mercê toda a brevidade para evitarmos o parem [o frete] se lhe demoras; pois pella escriptura nos obrigamos a descarga la em 25 dias uteis; e terão Vossa Mercê mui para cuidado na descarga, em que não haja descaminho e para os evitar terão a bordo duas peçoas fieis de dia e de noite athe dar o resto; ca mandarão ver e buscar, para que não fique algum sal oculto a bordo e o mesmo cuidado havera em terra quando se descarregar das embarcaçoins para os armazens." (Idem, vol. 5, pp. 377-378, Carta 1365)

dos pelas Ordenações do Reino, poderiam prover os oficiais indicados pelo contratador do sal, bem como gozar de proteção régia. Idem, pp. 102-103. 
Sobre as condições do contrato do sal, as de número 2 e de número 8 merecem destaque:

"(...) 2) Com condição que nenhum mestre das embarcaçoens que emtrarem na praça de Santos e outros quaisquer portos da cappitania de São Paulo poderão levar mais que hum alqueire de sal para seu gasto, e achando sse the ou procurando sse lhe que levava mais algum seu ou de partes serão prezos e da cadea pagarão cem mil reis, $e$ perderão a embarcação em que lhe for achado ou denunciado, e provado judiçialmente sem mais ou-tra ordem que esta condição e a mesma pensa se praticara com as canoas e pessoas que nellas condozirem sal, que não seja do estanco delle contratador. (...)"

"8) Com comdição que o governador da cappitania de São Paulo ouvidores da comarca da mesma çidade e de Pernagua ofeçiais da camara dellas e de todas as mais villas pertençentes a mesma cappitania capitaes mores nem outras quaisquer justiças de qualquer qualidade que seja se poderão intrometer por qualquer modo via ou maneira que seja nas vendas do sal deste contrato, nem lançarão tributo nem farão sobre elle postura alguma inda que seja achado em poder de pessoas particolares constando que o comprarão a elle contratador(...)." (Idem, vol. 4, pp. 92-93, Carta 693)

Ora, sendo monopólio régio a circulação mercantil do sal, cujo contrato fora diretamente elaborado entre o Conselho Ultramarino e os negociantes, como constatar irregularidades no negócio e questionar o poder régio que deferiu o contrato? Notamos que o sal gerou muito mais problemas do que maximização dos lucros, tendo em vista os transtornos e embaraços proporcionados pelos "descaminhos" do sal em São Paulo, motivados por tensões entre os "donos do sal" que se achavam na terra e com os órgãos de poder local, as câmaras das vilas. 
Em 27 de julho de 1727, João da Roza avisa que há na terra mais de 16 mil alqueires de sal e havia ainda a espera de mais uma sumaca que estava vindo da Bahia com mais sal, sendo vendido a 3,5 patacas que faz 1.120 rs (Cf. Idem, vol. 4, p. 17, Carta 659). Bernardo Ruiz do Valle, juiz-de-fora da vila de Santos e procurador do contrato junto à esfera política, fala de 14 mil alqueires de sal, mas prevê que, mesmo não havendo grandes lucros, não haverá grandes prejuízos no negócio (Idem, vol. 4. p. 28, Carta 666), ao contrário do que diz João Francisco Muzzi, afirmando que seria melhor mandar mais tecidos e panos para São Paulo para recuperar os prejuízos que teria com a fracassada venda do sal (Cf. Idem, p. 50, Carta 677). A abundância do produto colocou em risco o investimento do comércio do sal na capitania, e repetidas vezes os agentes mercantis de Pinheiro alertam sobre a super-oferta do produto. Vê-se que o mercado paulista concentrava grande estoque de sal e a preço inferior do estipulado pelo contrato, ao passo que, em relação ao sal legal, havia argumentos de carência de sal ou de um carregamento menor estipulado pelo contrato, ou a irregularidades das comunicações marítimas rumo a Santos (Lifschitz, 1950, p. 521). Adiantados cinco meses para vigorar o contrato do sal, Francisco Pinheiro já enviara à capitania os 662 moios de sal, o equivalente a 7 mil alqueires, para serem estocados nos armazéns de Santos; qual foi a surpresa em deparar-se com milhares de alqueires de sal no mercado privilegiadamente seu!

Pedro Fernandes de Andrade, em carta de 17 de março de 1728, comenta que ainda há na cidade mais de 15 mil alqueires de sal oriundos de particulares, e que a capitania não teria como consumi-lo em um ano, a fim de sair de circulação o sal ilegal. O negócio do sal para a agência de Francisco Pinheiro passou a ser afetado com essa concorrência ilícita, posto que o direito de venda do sal fosse exclusivo aos contratadores, não prevendo, obviamente, esta desvantagem econômica imposta pelos "donos do sal" presentes em terras americanas, captando sal oriundos da Bahia, Pernambuco e da própria vila de Santos, no nome do comerciante Valentim Ribeiro a preços que atingem as cifras de 1.120 rs (Lisanti Filho, 1973, vol. 4, p. 14, Carta 656). Dentre os comerciantes clandestinos, também estavam os "reverendos padres da companhia [de Jesus que] costuma vir aqui a sua fragatinha, e emtre o mais que tras vem sal para este comvento, e de São Paulo". Minas Gerais, antes grande consumidora do sal paulista, "não se vendera para ella hua so pedra", pois o sal do contrato do Rio de Janeiro sai muito mais barato (Idem, vol. 4, p. 58-61, Carta 681). 
O mesmo agente, em carta de 18 de setembro de 1727, avisa para que não se arremate o contrato do sal para o triênio de 1730-1732, por conta dos "donos do sal" que aqui se acham. (Idem, vol. 4, p. 38. Carta 671)

O excesso de sal na capitania foi refletido por Muzzi devido à liberdade que foi dada ao antigo contratador em mandar sal para a região, e não fora Francisco Pinheiro informado sobre tal situação em São Paulo. A busca pelo sal concentra-se no Rio de Janeiro, pois lá, embora tenha que se fazer grande desembolso, o preço de 1.120 rs é mais vantajoso do que em Santos, pois o valor do alqueire fixado pelo estanco era de 1.920 rs. Para Muzzi, o preço do sal deveria ser negociado no contrato na faixa de 1.280 a 1.500 rs para ter boa saída no mercado interno e que, para ter algum lucro com sal, teria de vendê-lo a um preço mais barato ou então reclamar junto ao Conselho Ultramarino os prejuízos sofridos e os consideráveis desembolsos que sofrerá, pois a vila santista estava prevenida por sal de 2 a 6 anos (Idem, vol. 4, p. 48, Carta 677). O fenômeno presente nas cartas, de criticar a diminuição do valor do alqueire de sal surpreende, pois consideravam os monopolistas sujeitos ávidos por lucros, inclusive lançando mão de diversos expedientes, como a especulação, forçando uma alta nos preços (Piza, 1898, pp. 280-281).

Impetrando requerimentos junto ao Conselho Ultramarino, alertando sobre a situação concorrencial desvantajosa para este monopólio régio a fim de desembaraçar o comércio do sal, Pedro Fernandes de Andrade recebera uma procuração judicial do dito Conselho permitindo a exclusividade comercial, bem como o litígio do sal estocado na capitania. Graças a esta ordem foi possível, por exemplo, a interrupção dos negócios dos padres que "conduzirão 132/2 alqueires de sal, a tanto que lho achamos e requeremos auto de tomadia nelle". Também tomou o sal de atravessadores que desrespeitam o perímetro legal do contrato. Ao tentar embargar um carregamento de 13 alqueires de sal indo para Laguna - área adstrita à capitania de São Paulo - e outro carregamento de sal indo para Cuiabá, os comerciantes pediram que fosse se entender com o contratador do Rio de Janeiro e com o general daquela capitania; alicerçado com os requerimentos e despachos do Conselho Ultramarino, deu auto de tomadia no carregamento (Lisanti Filho, 1973, p. 81, Carta 691). 
Contudo, o respaldo legal, garantindo a proteção do contrato do sal para Santos, não fora levado a sério pelos "donos do sal". Em 28 de abril de 1729, mesmo realizando ações litigiosas e embargando o sal clandestino e concorrencial, Pedro Fernandes de Andrade frustra-se ao saber que representações eram despachadas para o Conselho Ultramarino, questionando a procedência dos autos de tomadia (Idem, vol. 4, p. 81, Carta 691). Tivera desenganos com a desobediência dos negociantes locais quando o juiz-de-fora da vila, conservador do contrato régio do sal, mesmo dando o "Cumpra-se" nos termos contratuais para proibir a ação dos "donos do sal",

"pois nem o alvara de Sua Magestade que Deus guarde lho ordenava, nem a carta que tinha reçebido do conselho ultramarino, nem as condiçoens que dito senhor comfirmou ao contrato tal negavão, e asim que o contrato havia ter prençipio no primeiro de janeiro comforme o alvara e carta que elle tinha reçebido do conselho $e$ as partes tambem havião vender o sal que tinhão, e não puderão vender anteçedente, e tanto que tive este desemgano, na verdade me vi na maior consternação paraçendo me que este dizer era deregido a dar satisfação a algum empenho que tivesse pelos donos do sal(...)",

que são de nome nesta terra (Idem, vol. 4, p. 59, Carta 681). A truculência era tamanha que chega a afirmar que, com todos os esforços para conseguir dar utilidade de seu contrato e prejuízo aos donos do sal, "estes me tem prometido tirar a vida, que menos estimo o perde 1la que dar motivo a que com justa cauza forme Vossa Mercê e seu soçio queixas contra minha pessoa." (Idem, vol. 4, p. 75, Carta 689)

Entendemos, assim, que a primeira dimensão que "descaminhou" a atividade salineira de Francisco Pinheiro na capitania de São Paulo foi a presença desses "donos do sal". Emprestamos a expressão do agente Pedro Fernandes de Andrade para caracterizarmos a atuação desses negociantes de sal ilícito. Não é possível, no entanto, detectarmos a natureza social e seu grau de hierarquia no interior da elite paulista a partir das fontes; temos alguns personagens turvos, como um comerciante denominado Valentim Ribeiro, os "reverendos padres da companhia de Jesus" e aqueles de "nome desta terra". 
São personagens importantes, indubitavelmente, pois atuam nos poros do comércio monopolista, ainda mais pelo fato de deterem este "precioso condimento". Para adquirir sal, partiam para o contrabando do produto. Possivelmente os "donos do sal" estivessem atrelados a camadas mais abastadas de São Paulo, amarrados nas "teias mercantis" ou "sedimentadas no processo de mercantilização" da capitania, pois a própria condição econômica de São Paulo permite inferir que seus negócios estão ligados ao abastecimento (Blaj, 2002; Maranho, 2006; Borrego, 2006), mas preferimos, no momento, enfatizar a tensão entre a prática do comércio ilícito do sal com a empresa do estanco salineiro.

Conforme vimos, no mercado regional paulista a concentração de sal armazenado para venda chegava a atingir mais que o dobro do previsto no contrato trienal: para São Paulo, Santos, sertão e minas, a quantidade estipulada para o abastecimento fora de 7 mil alqueires, enquanto que, de acordo com as cartas, há menção de 14 a 16 mil alqueires de sal ilegal disponível para circulação comercial oferecidos com um preço menor que o preço estabelecido pelo estanco. Impressiona-nos a grande demanda do sal clandestino, reflexo da procura do gênero. $O$ argumento usado é que "se não gastarão mais de sete mil alqueires, em cada hum anno, e assim o querião justeficar, os donos do sal partecolar." (Lisanti Filho, 1973, vol. 4, p. 70, Carta 686) A pouca oferta de sal nas regiões de São Paulo, Santos, das minas e sertões possibilitou a formação de uma rede de fornecimento de sal para estas regiões, afinal, como o abastecimento subordinava-se ao Rio de Janeiro, a preferência recaía para a sua própria capitania e as Minas Gerais e São Paulo ficavam à margem desta distribuição.

Provavelmente, os negociantes apropriaram-se do porto de Santos para articular-se a outras regiões e obter o sal para o seu mercado. Já que o porto de Santos não estava inserido na dinâmica comercial atlântica, como o do Rio de Janeiro, especializou-se no comércio costeiro ou intrainsular e, assim, fortaleceu a circulação de mercadorias coloniais e europeias na costa em direção ao interior (Moura, 2010, p. 231). Agindo paralelamente ao comércio oceânico, a navegação de cabotagem permitia a articulação com outras regiões litorâneas em busca de mercadorias e, no nosso caso, do sal, como se evidenciou na documentação a vinda de sal da Bahia e de Pernambuco para a região paulista. Infelizmente, na mesma documentação não encontramos 
evidências da procedência deste sal, se era oriundo de Portugal e comercializado por outros Estados, pois a exportação e transporte não estavam somente nas mãos dos portugueses; ao seu lado debruçavam os hanseáticos, os neerlandeses, os bretões e os normandos que, ao fazerem os fretes de produtos ultramarinos nas rotas da África, Oriente e Brasil, aceitavam um retorno em sal, depois de largarem em Portugal a carga que haviam trazido (Rau, 1984, p. 282), o que levaria comercialização marginal deste sal nestas praças. Ou das salinas das costas brasileiras, "nas regiões correspondentes ao Ceará, Rio Grande do Norte, Paraíba, Pernambuco, Alagoas, Sergipe e também em Cabo Frio, na Capitania do Rio de Janeiro", pois a extração nessas regiões, mesmo reduzindo-a apenas para o consumo local, seria impossível proibi-lo nestas regiões litorâneas favorecidas geograficamente ideais para a produção do sal marinho (Ellis, 1955, p. 28). Neste caso, ficamos no campo das conjecturas sobre a procedência deste sal, mas podemos inferir que a ação administrativa e fiscalizadora nos portos periféricos, como Santos, dispunha frouxamente na alfândega, sendo atraente para esses negociantes, pois contavam com recursos de controle e fiscalização menos rígidos (Moura, 2010, p. 231), flexibilizando a ação de contrabandistas e atravessadores de sal para a praça paulista.

Pedro Fernandes de Andrade mostrou muita disposição em salvaguardar o monopólio do sal para a capitania, defendendo com a própria vida, caso necessário. Ações litigiosas, embargos, confiscos, requerimentos foram instrumentos usados para preservar a exclusividade mercantil e suprimir a ação dos "donos do sal". Por sua vez, estes relutavam em obedecer ao contrato e ao alvará de Sua Majestade, cabendo-nos, assim, salientar a petulância desses colonos em contrariá-los e, inclusive, questionando junto ao Conselho Ultramarino a procedência dos autos de tomadia. Pleitear em Lisboa os direitos comerciais sobre o sal colocam-nos também como empreendedores coloniais desde que estas atividades estivessem sob o controle e o arbítrio reais.

O rei era o único árbitro capaz de mediar os conflitos existentes, sobrepondo-se, inclusive, sobre a legislação e decretos. "Ao alterar essas jurisdições, o rei poderia manipular aqueles que poderiam exercer controle legítimo, e assim participar e se beneficiar de sua própria fatia do comércio ilegal." (Pijning, 2001, pp. 402-403) Podemos, então, entender a atitude dos "donos do sal" ao Conselho Ultramarino 
em recorrer das ações litigiosas aplicadas por Pedro Fernandes de Andrade a fim de impedir o comércio ilegal; também compreendemos a consternação do agente ao receber a informação de que "as partes tambem havião vender o sal que tinhão", mesmo não tendo conseguido vendê-lo antecipadamente.

Alinhavemos nossa reflexão sobre o exclusivo comercial. Fernando Novais (2001), como citamos há pouco, considera que o regime do comércio exclusivo garantia à Coroa a extração e o acúmulo primitivo de capitais, pois à colônia não estava reservado o papel de construção de concorrência no mercado luso-americano, já que o monopólio de determinados produtos, como o sal, conferia à metrópole os direitos de produção e distribuição em benefício da sua política econômica mercantilista. O esforço para preservá-lo origina-se como condição de funcionamento do próprio sistema colonial, com a subordinação política e econômica dos domínios ultramarinos em vistas de reverter os capitais para a metrópole, que, invariavelmente, forjaria o "arranque" da sua economia no cenário europeu e a constituição de um "capitalismo integral".

Dentro desse cenário, as práticas contrabandistas, como as encaradas pela agência de Francisco Pinheiro em São Paulo, longe de serem fissuras que desestruturem as relações exclusivistas entre metrópole e colônia, para o autor, aparece como integrante da lógica acumulativa. O sal ilegal circulante na capitania não emerge como uma ameaça à política de monopólios, pois, 1) a Coroa já se beneficiara das propinas recebidas pela concessão do estanco; 2) embora, teoricamente, o exclusivo surja como uma atividade econômica segura, não era isento de riscos e perdas financeiros ${ }^{7}$ e 3) os "donos do sal" que, embora sabendo as consequências da marginalidade (embargos, apreensões, prisões), também estavam empenhados nas perspectivas de superlucros coloniais, ao oferecer preços melhores pelo gênero. Lembremonos, por exemplo, quando João Francisco Muzzi informa a Pinheiro que, para ter algum lucro com o comércio do sal, seria necessário

7 O negociante baiano Manuel Dias Filgueiras, ao arrematar em 1700 o contrato do sal para o Estado do Brasil para o período de 1702 a 1712, perdera grandes cabedais com este estanco, levando-o a encampação do mesmo. Os motivos foram as arbitrariedades da Coroa, ao elevar o custo do moio do sal, de $2 \$ 000$ a $7 \$ 000$, repassando o custo ao consumidor da colônia que antes pagava $480 \mathrm{rs} \mathrm{e}$, em 1710, chegou a pagar 720 rs, levantando inquietações populares, invasão em sua residência e a recusa do povo em pagar o novo preço; o ataque corsário francês de Duguay-Trouin no porto do Rio de Janeiro, que roubara o sal de seu contrato para provimento da capitania; a execução das dívidas por D. João V em favor da Fazenda Real, sequestrando-lhe seus bens e de seus fiadores (Cf. Ellis, 1955, pp. 134-137). 
abaixar o preço do alqueire de 1.920 rs para algum valor entre 1.280 e 1.500 rs. "É certo que o contrabandista devia, para encontrar campo para suas atividades, oferecer preços um tanto melhores pelos produtos coloniais, bem como oferecer produtos europeus a preços mais baixos do que os mercadores metropolitanos. Mas nunca num nível que significasse uma perfeita concorrência comercial, pois do contrário, o que os compensaria dos altos riscos?" (Novais, 2001, p. 91) Estabelecer uma margem equivalente dos preços entre o sal do estanco e o sal ilegal convergiria ao mesmo ponto: garantir a acumulação de capitais através da exploração colonial.

Pensamos que o poder explicativo baseado no "sistema colonial" homogeneíza a relação entre metrópole e colônia, condensando o processo de colonização moderna dentro de uma sociedade alicerçada em uma cultura do Antigo Regime em torno da acumulação primitiva de capitais, sentido último para o desenvolvimento integral do capitalismo europeu. Embora a ambição de Francisco Pinheiro e dos "donos do sal" estejam concentradas em amealhar lucros com o trato do sal, seja na legalidade ou na ilegalidade, podemos problematizar, por exemplo, que ambas as formas de extração de excedentes para além-mar estejam relacionadas a sustentar um "projeto arcaico" no Império lusitano, mantendo uma sociedade estamental e aristocrática, que se reproduz no interior das colônias (Fragoso e Florentino, 1993).

Luiz Felipe de Alencastro (2000) explica que o funcionamento destas redes locais de abastecimento emerge na colônia devido às dificuldades dos conquistadores reinóis em assegurar o controle dos nativos e dos excedentes econômicos. Tais redes mercantis não convergem necessariamente às fímbrias institucionais metropolitanas, exigindo que a Coroa colonizasse primeiramente os seus colonos. De um lado, o domínio dos nativos não resultaria na exploração econômica para a metrópole, os excedentes seriam consumidos pelos próprios nativos ou por outras redes, e controle do trabalho nativo não seria convertido em capitais e mercadorias para a metrópole. Por outro lado, ainda que a teia ibérica se fixasse no interior das colônias e captasse os excedentes econômicos, não significaria o reforço do poder monárquico, pois trocas oceânicas e a ascensão de comerciantes regionais constroem novas forças sociais tanto na metrópole como nas colônias. "De maneira que o domínio ultramarino nem sempre desemboca na exploração colonial, como também não instaura de 
imediato a obediência do colonato e dos negociantes ao poder metropolitano." (Alencastro, 2000, p. 12) A instalação do monopólio de anis em Goa, na Índia, realça as dificuldades na colonização: os interesses do comércio, estando acima da fidelidade à Coroa, teceram o aumento do contrabando e do comércio regional, o enfraquecimento da autoridade portuguesa e os excedentes coloniais, transformados em produção mercantil, fogem às redes metropolitanas (Cf. Idem, p. 16). Aproximando nosso estudo de caso ao que Alencastro argumenta, a atuação dos "donos do sal" na capitania de São Paulo é operacionalizada à margem do domínio mercantil do exclusivo, como também na desobediência dos colonos em acatar o projeto colonizador metropolitano.

Charles Boxer (2002) menciona que, "[e]ssas práticas [de contrabando] eram inevitáveis num momento e numa época em que todos os governos se esforçavam para implementar monopólios de qualquer espécie, em que não raro se exigiam altas taxas alfandegárias sobre mercadorias de grande procura." (Boxer, 2002, p. 349) Havia uma estrutura econômica e social que garantia juridicamente o exclusivo sobre alguns produtos reservados ao rei e aos arrematantes dos monopólios. O contrabando, contudo, oferecia concorrência comercial ao erário real e amealhava lucros a partir desses tratos, lesando os cofres metropolitanos.

Roquinaldo Ferreira (2010) cita que, entre 1709 e 1761, foram mais de vinte leis que proibiam comércio e ancoragem de navios estrangeiros em portos brasileiros, denotando, assim, que era intensa a atividade de comerciantes agindo às margens dos monopólios comerciais. Tentativas infrutíferas, nos dizeres do autor, pois os contrabandos causavam imensos prejuízos fiscais aos cofres régios, mas paralelo aos danos à Coroa, gradativamente "o contrabando não só se tornou a pedra angular das relações comerciais - sangrando continuamente o erário -, mas também contribuiu significativamente para o surgimento de centros de comércio fora da metrópole e das relações comerciais diretas entre colônias." (Ferreira, 2010, pp. 203-241)

Não só a elite mercantil paulista ameaçara a validade do contrato do sal. As câmaras municipais de Santos e de São Paulo também interferiram nos preços e nos negócios. Conforme vimos, a Câmara reportou requerimento a El-Rei para diminuir o valor do produto. Em carta de 27 de julho de 1727, Pedro de Andrade espera por 
"maduros conselhos" de Francisco Pinheiro sobre a repugnância encontrada pelos camaristas acerca do valor do alqueire do sal; afinal, vendia-se o produto a 1.120rs na região, e na Ilha de São Sebastião o valor era de 960 rs. Sob protestos e o regimento real em mãos, a Câmara aprovou a validade do atual contrato, mas que não aceitaria tais valores para o próximo (Lisanti Filho, 1973, vol. 4, p. 20-21, Carta 661). O clima ficou amenizado temporariamente; mas a câmara mandou ao Conselho Ultramarino a mudança do preço para 1.280 rs. Cedendo às pressões, Francisco Pinheiro reporta-se a Pedro Fernandes de Andrade dizendo que,

"em vista de os senhores da camara e o povo não quererem ademitir o preço do sal a 1.920 rs que sem duvida era uzurbitante fizemos requerimento a Sua Majestade que Deus guarde, e houve o contracto por de nenhum effeito, e nos mandão entregar, para VM. o venderem pello preço da terra que sera a 1.280 rs pagando deste preço o cruzado que se acha imposto no dito genero e como podera haver quem compreeste todo junto a dinheiro de contado..." (Idem, vol. 5, p. 391, carta 1379)

Para prejudicar a venda do sal, em São Paulo,

"Lançarão os camaristas della em cada hum alqueire de sal 160rs de trebuto para o chapim, e tanto que assim se poblicou acodimos logo com hua procuração narando lhe o grande prejuizo que de semelhante emposto se seguia ao contracto na abstenção que muitas pesoas havião fazer em comprar o sal, e protestando lhe por elle, pois que a condição 17 nega as camaras, e outros o lançar sobre o sal posturas". (Idem, vol. 4, p. 79, Carta 690)

Às Câmaras não estavam reservados direitos em interferir nas cláusulas contratuais assinadas em Lisboa, pois os contratos expressam a vontade e a soberania régia sobre quaisquer condições comerciais e os 
privilégios de seus arrematantes. A apreciação nas câmaras das vilas em lançar um imposto sobre uma mercadoria de exclusividade régia feria o modus operandi do monopólio, pois elevariam seus interesses locais em detrimento à Coroa.

A razão implícita na aprovação da Câmara para a aplicação do tributo residia na adoção da mensuração a granel do sal. A mensuração do sal, para os camaristas, deveria seguir a medida da terra e não a prevista pelo contrato, pois, ao valor pago pelo sal seguindo a mensuração local, obtinha-se quantidade maior do produto em relação à medida contratual. A desigualdade no sistema métrico do sal favorecia aos da terra, pois levariam uma quantidade maior do produto pelo mesmo valor pago ao sal mensurado pelas medidas do monopólio. Pedro Fernandes rejeita tal condição, "nos não avemos fazer porque em nada pertendemos exçeder do que VM. ajustarão com o conselho ultramarino e so sim remeteremos por vias todos os requerimentos para servirem a VM. de governo no que lhe convier fazer, e pelo que respeita ao sal." Posição diferente adotada pelo antigo contratador do sal, que, além de vender pela medida da terra, embolsava mais 160 rs por alqueire, precisamente a mesma quantia exigida pela Câmara na tributação (Idem, vol. 4, p. 55, Carta 679). Este "excedente" de 160 rs extraído pelo contratador seria uma exigência da Câmara para permissão do comércio do sal através do pagamento de propinas?

Teríamos muita imprecisão em estabelecer a associação de pagamento de tributos ou tarifas à Câmara para permitir a circulação mercantil do sal. Contudo, este órgão de poder muda seu comportamento junto à agência de Francisco Pinheiro sobre esse monopólio régio. Pedro Fernandes de Andrade, em 2 de maio de 1729, diz a Pinheiro que as câmaras paulistas, mais do que ninguém, estimam que o sal metido na capitania seja feito pelo contratador de Lisboa, pois não sabiam os camaristas que entre os contratadores Francisco Pinheiro tivesse nome e que muito convinha ficarem com o contrato outro triênio. Havia, para tanto, condições para o bom proveito do comércio do sal na capitania:

"não quizemos faltar em comonicar lhe a forma, e os meios que aqui consultarão para serem secorridos, e assim isto como o mais que lhe temos parteçipado os podera rezolver a tomarem outro trienio que lhe ão de dar por des mil 
cruzados cada anno pouco mais ou menos visto Sua Majestade que Deus guarde olhar para o que esta camera lhe reprezentou, e reprezenta, e sera com as condiçoens que lhe temos remetido por tres vias; este dezembro que nos temos de Vossa Mercê ficarem outro trianno com este contracto por reconheçeremos que nelle ão de restaorar o prejuizo deste, e utelizarem sse [do novo contrato]." (Idem, vol. 4, pp. 90-91, Carta 693)

A ajuda anual de 10 mil cruzados e a proteção e guarda de Sua Majestade à Câmara seriam "moedas de troca" para que a agência de Francisco Pinheiro pudesse negociar "livremente" seu sal e recuperasse o prejuízo obtido nesta empreitada empresarial em São Paulo. Salta-nos aos olhos esta negociação, pois não encontramos no bojo documental da agência empecilhos que prejudicassem a venda de suas fazendas em Santos, São Paulo ou nas regiões de Cuiabá ou Goiás. Justamente o sal embaraça as suas atividades comerciais e que, para valer-se dos bons negócios oriundos da "exclusividade régia", teria de compactuar com os interesses e as condições locais e efetivar, com a chancela do poder camarista, uma permissão consagrada por El-Rei. É escandalosa a proposta feita a Pedro Fernandes de Andrade para que Francisco Pinheiro e seus sócios arrematem o estanco do sal para o triênio 1730-1732 a fim de recuperar seus prejuízos, pois à Câmara reserva o direito de sobrepor a efetividade do contrato a partir dos seus interesses em detrimento àquilo que fora negociado em Lisboa no Conselho Ultramarino entre os contratadores e o rei. Lembremos que, além dos 10 mil cruzados anuais destinados para a Câmara, os oficiais também almejam que "Sua Magestade que Deus guarde olhar para o que esta camera lhe reprezentou, e reprezenta": objetiva-se o acesso do poder local ao reconhecimento e premiação do rei no interior do Império.

Ora, como a Câmara assumia o papel de agente organizador dos interesses municipais, representando as demandas sociais e econômicas dos seus habitantes, atuava como porta-voz das queixas e súplicas da população local, "muitas vezes contestando as normas governamentais e metropolitanas, constituindo-se como um espaço privilegiado de diálogo e negociação com a Coroa." (Borrego, 2006, p. 133) O caráter absolutista do rei, desta forma, esvazia-se, e evidenciamos 
o espaço de negociação e conflitos entre os interesses locais e os interesses régios. $\mathrm{O}$ monopólio régio do sal, teoricamente, estava protegido das intromissões dos oficiais da Câmara, de negociantes, vereadores ou quaisquer autoridades locais, sob pena de pagamento de perdas e danos ao contratador do sal (Ellis, 1955, p. 85) e, conforme vimos, a Câmara resolve lançar mão de um tributo sobre o sal para proveito próprio.

Estes percalços encontrados por Pinheiro e seus agentes, durante a sua empreitada comercial em São Paulo com o estanco do sal, evidenciam a tensão existente entre colonos e a autoridade régia. John Monteiro (1999) lembra que este ponto de atrito entre ambos remonta desde o século XVII, sobretudo após a instauração do monopólio em 1631. "Inúmeras representações foram despachadas pelas câmaras municipais da capitania, queixando-se da omissão dos contratadores e dos preços excessivos. Parte do problema residia no descaso da coroa e dos contratadores, pouco sensíveis à demanda efetiva da população colonial." (Monteiro, 1999, p. 3) O mau fornecimento do sal previsto no contrato não conseguia atender integralmente ao mercado paulista, ocasionando ondas especulativas sobre o preço do produto e o contrabando.

Estes "descaminhos do sal" em São Paulo levaram, inclusive, a ações que extrapolavam os limites da negociação entre colonos e o Conselho Ultramarino, como a revolta do sal em 1710. Valendo-se da violência como forma de promover justiça, alegando a carestia do produto na região de Serra Acima, o potentado senhor de terras e de escravos da região de Jacareí, Bartolomeu Fernandes de Faria, em outubro daquele ano, desceu a Serra do Mar com uma escolta de homens e escravos e saqueou na vila de Santos, sem muita resistência da guarnição local, o armazém contendo o sal do monopólio. Após o assalto, conduziu o produto Serra Acima e o repartiu entre os consumidores das redondezas.

A revolta coroou a aguda conjuntura da região, em que o sal estava sendo comercializado entre os abusivos valores de $12 \$ 000$ a $16 \$ 000$ quando o preço estipulado era de 980 rs por alqueire, e a série de boatos dando conta de uma quantidade considerável de sal estocada em Santos, entre 500 e 600 alqueires, que seriam reembarcados para o Rio de Janeiro, por não haver compradores na praça paulista. A ação liderada por Bartolomeu Fernandes de Faria apenas denota a 
má administração do contratador do sal e da própria vila de Santos em não distribuir o referido condimento, tanto que, em 1725, uma investigação apurou que "nos anos entre 1708 e 1711, os contratadores 'não meteram sal' na praça de Santos." (Cf. Idem, p. 5)

De certa forma, a revolta do sal de 1710 confirma a ausência da justiça metropolitana no mercado colonial paulista. As facções locais alinham-se em torno de um poder privado que é erigido graças à ausência da justiça régia. $\mathrm{O}$ assalto ao armazém do sal é uma das evidências deste poder local instituído pautado na força e na violência, pois "ao desnudar a incompetência da guarnição de Santos, constituiu uma afronta direta à imagem da autoridade régia na região." (Cf. Idem, p. 7) Métodos violentos também foram usados dezoito anos depois na tentativa de validar o contrato do sal em São Paulo, basta lembremos quando Pedro Fernandes de Andrade confessara a Francisco Pinheiro que os "donos do sal" ameaçaram-no tirar a vida. A intimidação pessoal e a truculência também se seguiram a partir dos problemas do sal.

Diante dos embaraços encontrados no comércio do sal em São Paulo, conflitando com os "donos do sal" e os poderes camaristas locais, o contrato do sal é revogado pela Coroa. Em carta de 1729, Francisco Pinheiro remete ao conservador do sal, o juiz-de-fora Bernardo Ruiz do Valle, "as ordens [a Pedro Fernandes de Andrade] porque consta haver me Sua Magestade removido o contracto do sal que arematei nessa cappitania no cazo que este se valha de Vossa Mercê. algua cousa." (Lisanti Filho, 1973, vol. 5, p. 392, Carta 1381) Afinal, o monopólio não funcionaria diante do quadro apresentado pelos agentes de Pinheiro ao Conselho Ultramarino e ao rei, tendo em vista que, por um lado, negociantes locais controlavam a circulação de sal proveniente de redes mercantis ilícitas, por outro, as Câmaras impediam a efetividade do monopólio, insurgindo-se contra o preço aprovado pela Coroa, sujeitando a comercialização do produto à medida da terra e somente com a participação dos camaristas no contrato, com

8 O régulo Bartolomeu Fernandes de Faria, após ataque à casa do ouvidor Souto Maior no ano de 1713, justificado pelo grande afinco que este tivera em querer prender o dito "justiceiro", refugiou-se no Vale do Ribeira, região ainda mais afastada para a justiça metropolitana. Acusado pelo assassinato de dois homens, fora capturado em 1718, graças a uma diligência comandada pelo ouvidor Rafael Pires Pardinho. Mandado para uma prisão em Salvador, não chegou a ser ouvido pelo Tribunal da Relação: em 2 de julho de 1719 falecera, acometido pelo desânimo, pela idade e uma doença grave. (Monteiro, 1999, pp. 7-8) Contudo, em seu processo criminal, nada consta sobre o saque do sal realizado em 1710. 
o "socorro" de 10 mil cruzados ao ano e a proteção régia à capitania, é que cumpririam com as condições contratuais acertadas em Lisboa.

\section{Considerações Finais}

Buscamos discutir neste artigo o caso da atuação do mercador de grosso trato Francisco Pinheiro na capitania de São Paulo, especificamente na sua atuação junto ao contrato régio do sal referente ao período de 1728 a 1730. Foi notado que, ao associar-se numa atividade que, teoricamente, garantiria lucros fixos, deparou-se com a circulação ilegal do produto na capitania, tecida a partir da ação dos "donos do sal". A segurança comercial obtida com o monopólio não apresentou efeitos positivos para sua empreitada empresarial, gerou transtornos e desenganos para o administrador do sal na capitania, pois os "donos do sal" presentes em São Paulo não permitiram a aplicabilidade do contrato do sal, fazendo insurgir, assim, conflitos entre a agência de Francisco Pinheiro e os comerciantes locais, pois estes não se sujeitaram às condições do contrato e aos pareceres do conservador do sal e do Conselho Ultramarino.

Os "descaminhos do sal" tornaram os negócios de Francisco Pinheiro e de seus agentes imprecisos, pois, de um lado, a ação dos "donos do sal" deflagrou uma situação concorrencial, em que o sal circulante saía mais barato do que o sal do contrato, obrigando o ajuste de preços para inserir-se no mercado colonial. Por outro lado, as Câmaras Municipais de Santos e de São Paulo insurgiram-se contra as condições do contrato do sal, lançando tributos sobre o sal, condicionando a venda deste pela medida da terra e exigindo a formação de pactos políticos entre a agência, o rei e a câmara para o bom andamento do contrato régio na capitania.

Os "descaminhos do sal" percorridos por Francisco Pinheiro acentuam a presença de forças sociais e de mercados regionais que possuem certa autonomia em áreas onde o poder metropolitano não se cristalizou. Interesses dos "donos do sal" e das câmaras municipais, como vimos, confrontavam-se com a política metropolitana do exclusivo do sal, derivando as tensões na teia mercantil paulista, pois os objetivos de ambos não convergiam: a Coroa e Francisco Pinheiro almejavam aplicar o exclusivo para remeter capitais para Lisboa; as esferas locais de poder, "donos do sal" e câmaras, defendiam a continuidade da 
prática mercantil do sal clandestino e a discussão e até interferência nas determinações régias sobre a regulação do comércio local. Neste sentido, a experiência com os negócios salineiros na capitania de São Paulo revelou que, para se estabelecer neste mercado, era preciso mais que o próprio poder metropolitano: era necessário negociar a sua entrada nesta teia tramada pelos agentes locais.

\section{Referências}

ABREU, L. "Setúbal, o sal e o Além (sécs. XVI-XVIII)" In: I Seminário Internacional sobre o sal português. Porto: Instituto de História Moderna da Universidade do Porto - Faculdade de Letras, pp. 329-377, 2005.

ALENCASTRO, L. F. O trato dos viventes: Formação do Brasil no Atlântico Sul. São Paulo: Companhia das Letras, 2000.

AMORIM, I. “Monopólio e concorrência-A 'roda do sal' de Setúbal (Portugal) e as rotas internacionais (segunda metade do século XVII a inícios do de XIX)" In: A articulação do sal português aos circuitos mundiais: antigos e novos consumos. Porto: Instituto de História Moderna - Universidade do Porto, pp. 183-209, 2008.

ARAÚJO, L. A. S. Contratos e tributos nas Minas setecentistas: O estudo de um caso - João de Souza Lisboa (1745-1765). Niterói: UFF. Dissertação de Mestrado em História Social, 2002.

BLAJ, I. A trama das tensões - O processo de mercantilização de São Paulo colonial (1681-1721). São Paulo: Humanitas, 2002.

BORREGO, M. A. M. A teia mercantil: negócios e poderes em São Paulo colonial (1711-1765). São Paulo: USP, FFLCH. Tese de Doutoramento, 2006.

BOXER, C. O império marítimo português (1415-1825). São Paulo: Cia. das Letras, 2002.

ELLIS, M. "Comerciantes e contratadores do passado colonial”, In: Revista IEB (24), pp. 97-122, 1982. , O monopólio do sal no Estado do Brasil (1631-1801). São Paulo: Seção Gráfica USP, 1955.

FERREIRA, R. “A arte de furtar": redes de comércio ilegal no mercado imperial ultramarino português (c.1690-c.1750) In: FRAGOSO, J. \& GOUVÊA, M. F. (org). Na trama das redes: politica e negócios no Império português, séculos XVI-XVIII'. Rio de Janeiro: Civilização Brasileira, pp. 203-241, 2010.

FRAGOSO, J., FLORENTINO, M. O arcaísmo como projeto: mercado atlântico, sociedade agrária e elite mercantil no Rio de Janeiro (c. 1790-c. 1840). Rio de Janeiro: Diadorim: 1990.

FURTADO, J. F. Homens de Negócio; A Interiorização da Metrópole e do Comércio nas Minas Setecentistas. São Paulo: Hucitec, 1999.

GARCIA, J. M. “Apresentação” in: RAU, V. Estudos sobre a história do sal português. Lisboa: Editorial Presença, p. 9-17, 1984.

HONDA, L. Francisco Pinheiro: as atividades de um comerciante de grosso trato na América portuguesa (1703-1749). Campinas: Unicamp (IE) Dissertação de Mestrado em História Econômica, 2004.

LIFSCHITZ, M. “O sal na capitania de São Paulo no século XVIII” In: Revista de História, n. 4, p. 517-526, 1950.

LISANTI Filho, L. Negócios Coloniais; uma correspondência comercial do século XVIII. Brasília: Ministério da Fazenda; São Paulo: Visão Editorial, 1973. 5 volumes. 
MARANHO, M. F. O moinho e o engenho: São Paulo e Pernambuco em diferentes contextos e atribuições no Império Colonial Português (1580-1720). São Paulo: USP, FFLCH, Dissertação de Doutoramento em História, 2006.

MONTEIRO, J.M. "Sal, justiça social e autoridade régia: São Paulo no início do século XVIII" In: Revista Tempo. Niterói, v. 4, nº 8, pp. 1-14, 1999.

MOURA, D. A. S. de. "Subsistemas de comércios costeiros e internalização de interesses na dissolução do Império Colonial português (Santos, 1788-1822)" in: Revista Brasileira de História. São Paulo, v. 30, nº 59, pp. 215-237, 2010.

NOVAIS, F. Portugal e Brasil na crise do Antigo Sistema Colonial (1777-1808). São Paulo: Hucitec, 2001.

PEDREIRA, J. M. "Tratos e contratos: actividades, interesses e orientações dos investimentos dos negociantes da praça de Lisboa (1755-1822)" In: Análise social, vol. XXXI (136-137), pp. 355$379,1996\left(2^{\circ}-3^{\circ}\right)$.

PIJNING, E. "Contrabando, ilegalidade e medidas políticas no Rio de Janeiro do século XVIII" In: Revista Brasileira de História. São Paulo, v. 21, nº 42, pp. 397-414, 2001.

PIZA, A. T. "A miséria do sal em São Paulo" In: Revista do Instituto Histórico e Geográfico de São Paulo, n 4, pp. 279-295, 1898.

RAU, V. "Rumos e vicissitudes do comércio do sal português nos séculos XIV a XVIII" in: Estudos sobre a história do sal português. Lisboa: Editorial Presença, pp. 217-295, 1984.

SILVA, F. R. da. “O sal - produto tributado e mercadoria foraleira” In: I Seminário Internacional sobre o sal português. Porto: Instituto de História Moderna da Universidade do Porto - Faculdade de Letras, pp. 63-74, 2005. 